\title{
DETERMINANTS OF INTRA-INDUSTRY TRADE IN AgRICULTURAL ANd Food Products between Poland ANd EU Countries
}

\author{
Justyna Łapińska ${ }^{1}$
}

\begin{abstract}
The present study investigates the country-specific determinants of intra-industry trade between Poland and its European Union trading partners in agricultural and food products during the time period 2002-2011. An econometric model for panel data is applied for the analysis of the factors determining Polish bilateral intra-industry trade with European Union countries. The research leads to the formulation of a statement that the intensity of intra-industry trade in agricultural and food products is positively influenced by the intensity of trade with EU countries and the level of economic development of the member countries (as measured by the size of their GDP per capita). Increase in intra-trade turnover is also facilitated by EU membership and by the fact that Poland's trade partners use similar Slavic-based languages. Relative differences in the size of the economies and relative differences in Poland's and its trading partners' levels of economic development have a negative impact. The degree of the imbalance of trade turnover between trading partners also negatively influences the intensity of intra-trade exchange. The research confirms that the impact of all of the identified factors determining intra-industry trade is consistent with the predictions of the theory.
\end{abstract}

\section{Keywords}

Intra-industry trade, Agricultural and food products, Poland, European Union

\section{Introduction}

As a result of technological progress and structural transformation in the world's production and consumption, intra-industry trade has become the dominant form of trade exchange, particularly between industrialized countries. According to the most frequently accepted definition, intra-industry trade occurs when countries simultaneously export and

${ }^{1}$ Nicolaus Copernicus University, Faculty of Economic Sciences and Management, Gagarina 13a, 87-100 Toruń, Poland. E-mail: justlap@umk.pl. 
import finished products, semi-finished products, parts and components of products belonging to the same industry, which are close substitutes in production or consumption, or in both of these spheres together (Grubel and Lloyd, 1975).

Intra-industry trade is the subject of numerous theoretical and empirical analyses, leading to the creation of the theory of intra-industry trade, now considered to be an important completion of traditional theories of international trade.

Within the still being developed theory of intra-industry trade, the identification of factors determining intra-industry trade is continued. They are generally divided into two categories. The first includes country-specific determinants. These are the characteristics of the economies of trading partners involved in the exchange. The second group are the industry-specific determinants, i.e., the characteristics of the branch within which products are exchanged.

The purpose of this work is to identify the country-specific determinants impacting the intensity of intra-industry trade within Poland's trade turnover with EU countries in agricultural and food products.

\section{Country-specific determinants of intra-industry trade}

Literature on the subject points to a number of factors influencing the intensity of intraindustry trade. As follows from empirical studies, development of this type of exchange depends on the size of the economies of the trading countries, as measured by the size of their GDP. This factor is considered to be particularly important in gravity models of trade (not only intra-industry trade), in which it is a variable determining the mass of countries, which in turn determines the attracting strength of economies (see, for instance, van Bergeijk and Brakman, 2010; Pietrzak and Łapińska, 2014). Large markets foster the development of intra-industry trade, mainly due to the greater possibilities for extending production there, as characterized by increasing economies of scale. Moreover, as noted by Czarny (2002), a larger GDP frequently means that the country is better equipped in terms of capital, a condition which favours the development of the processing industry. Those goods subject to intra-industry trade are the diversified products produced by the processing industry. The existence of a positive relationship between the size of the economies of trading countries and the intensity of intra-industry trade is confirmed by numerous empirical studies (see, for instance, Clark and Stanley, 1999; Zhang and Li, 2006; Onogwu, 2013).

Differences between trade partners' GDPs are also important. The smaller these are, the more intense the intra-industry trade. This factor underlies Helpman's statement (Helpman, 1987), which showed that bilateral trade between countries is directly proportional to the product of their GDPs. Helpman proved the validity of his statement in relation to developed countries. He studied trade conducted by countries belonging to the Organization for Economic Cooperation and Development. Empirical tests of Helpman's statement were also carried out by a number of researchers in relation to non-OECD countries (see, for instance, Okubo, 2007; Czarny and Śledziewska, 2009). The results obtained by them indicate the existence of a negative correlation between intra-industry 
trade and large differences in the size of the countries involved in the exchange. There are, however, such empirical studies that do not confirm this relationship. According to Markusen and Venables (1996), comparable sizes of economies do not necessarily favour the development of intra-industry trade. Such trade can, in fact, be replaced by mutual direct investments. In empirical studies, differences in the size of trading partners are usually calculated according to the following formula (see, for instance, Zhang and Li, 2006):

$$
\begin{array}{r}
D G D P_{k t}=1+\frac{[w \ln w+(1-w) \ln (1-w)]}{\ln 2}, \\
w=\frac{G D P_{j}}{\left(G D P_{j}+G D P_{k}\right)},
\end{array}
$$

where:

$G D P_{j}, G D P_{k}-$ Gross Domestic Product of the country $j$ and its trading partner $k$.

The above index takes on values from the interval [0;1]. If the differences in GDP between countries are large, then the index approaches the value of 1 . When GDP is identical for both countries, then it equalizes 0 .

An important factor supporting the development of this type of exchange is a high level of GDP per capita. In affluent countries with a high GDP per capita, consumers are more likely to acquire diversified, i.e. more processed, products. Higher incomes mean that consumers can buy more variants of diverse goods or pay more and get the preferred variant of a diversified good. Such consumer behaviours (demand for various products) favours the development of intra-industry trade. This is confirmed by the results of empirical studies conducted by Loertscher and Wolter (1980) and Balassa and Bauwens (1987). Another way of interpreting the impact of this factor relates to the supply side of the market, or the resources of the production factors of a given country. Theoretical models (see, for instance, Helpman and Krugman, 1985) assume that a higher GDP per capita in the economy corresponds to a higher ratio of capital to labour. Countries where capitalintensive sectors outweigh relatively, produce relatively more diversified products, which in turn fosters the development of intra-industry trade (Bergstrand, 1990).

An important factor fostering the development of intra-industry trade is also slight differences between the GDP per capita of trading countries. These may demonstrate similar consumer preferences in the countries engaged in trade exchange. This interpretation refers to the concept of similarity of preferences created by Linder (1961), according to which the intensity and structure of trade largely depends on the degree of similarity between countries. GDP per capita can also be interpreted from the supply side, as an approximation of the proportion of productive factors in the economy (see, for instance, Clark and Stanley, 1999; Niem and Kim, 2010). Countries similarly equipped in capital and labour have similar opportunities to develop the processing industry that manufactures the differentiated products subject to intra-industry trade. These capabilities increase together with increases in the share of capital in the economy. Differences in GDP per capita between countries are estimated using the formula constructed as in the case of differences 
in the size of GDP of trading countries. Numerous empirical studies confirm the negative impact of large differences in GDP per capita of trading countries on the development of mutual intra-trade exchange (see, for instance, Turmo et al. 2005; Zhang and Clark, 2009; Sotomayor, 2012).

Other factors supporting the development of intra-trade are trade liberalization and economic integration. As a result of the integration processes, and more specifically, of trade policies conducted within integration grouping, two classic effects are revealed. These are the effect of trade creation and the effect of trade shift. The first effect denotes an increase in the volume of mutual trade exchange between the group partners as a result of the elimination of barriers to trade. It applies to goods that previously, i.e., under the conditions of the autonomous customs policies run by individual countries, were not imported because their prices after adding import tariffs were higher than domestic prices. The abolition of customs duties makes imported goods cheaper than those produced in the country. Consequently, a new trade stream is created which gets stronger when the level of tariffs increases and the difference in production costs is larger. The other effect is associated with a shift in existing trade flows and means the replacement of supplies from third country producers by supplies from producers from member states of the group, whose competitiveness has increased significantly as a result of the abolition of internal trade barriers.

Empirical studies (see, for instance, Globerman and Dean, 1990; Wakasugi, 2007; Sudsawasd, 2012; Ramakrishnan and Varma, 2014) confirm that, under conditions of imperfect competition and product differentiation, integration processes and the related process of removing barriers to trade are more conducive to the intensification of intra-industry trade than inter-industry trade. This is the case because those goods subject to intra-industry trade are close substitutes, and therefore they have a fairly high price elasticity of demand. The importance of integration processes for the development of intra-industry trade is associated not only with the reduction of trade restrictions, but also reflects the fact that the integration grouping includes countries with similar levels of economic development. The development of intra-industry trade is significantly affected by the geographical distance between trading partners. The significance of this factor is mainly related to costs of transport and the insurance of goods. In empirical studies, geographical distance is most frequently measured by the number of kilometres between the capital cities of trading partners. Sometimes the cost of sending a parcel by mail (a good) of a certain weight to a specific country is taken as the measure of distance. Crespo and Fountoura (2004) argue that such an approach in expressing distance is justified, because transport costs do not increase linearly together with increases in distance. The existence of a negative relationship between the geographical distance and the intensity of intra-industry trade is confirmed by empirical studies (see, for instance, Cieślik, 2000; Botrić, 2013).

As shown by empirical research, the cultural community of trading countries, in particular, a common or similar language, national identity, tradition and history, facilitate the development of intra-industry trade (Ekanayake, 2001; Mulenga, 2012). This is mainly due to easier communication, lower transaction costs and similarity in the structure of demand. 
Other factors affecting the development of intra-industry trade include a large share of processed goods in the trade volume and a considerable intensity of trade relations between the countries (Byun and Lee, 2005; Ekanayake, 2001).

Empirical studies confirm that the degree of trade imbalance exerts a negative impact on the intensity of intra-industry trade (see, for instance, Lee and Sohn, 2004; Thorpe and Zhang, 2005; Leitão, 2011). If trade between two countries is not balanced, then the intensity of the intra-industry trade index cannot reach its maximum value. The degree of trade imbalance is determined mostly by means of the following formula (Lee, Lee, 1993):

$$
T I M B_{j k}=\frac{\left|X_{j k}-M_{j k}\right|}{\left(X_{j k}+M_{j k}\right)}
$$

where:

$X_{j k}$ - the value of exports from country $j$ to country $k$,

$M_{j k}$ - the value of imports to country $j$ from country $k$.

The above index takes on the value of 0 , when the trade exchange between two countries is balanced, and the value of 1 if in the case of one of the countries its exports or imports (but not both exports and imports at the same time) equal zero.

\section{Intensity of intra-industry trade between Poland and European Union member states in agricultural and food products}

There are many methods for measuring intra-industry trade. An overview is presented by such authors as, for instance, Vona (1991), or Łapińska (2003). However, most empirical studies measuring the intensity of intra-industry trade employ the Grubel-Lloyd index, calculated according to the following formula (Grubel and Lloyd, 1975):

$$
G L_{i}=\frac{\left.\left(X_{i}+M_{i}\right)-\left|X_{i}-M_{i}\right|\right)}{\left(X_{i}+M_{i}\right)}=1-\frac{\left|X_{i}-M_{i}\right|}{\left(X_{i}+M_{i}\right)},
$$

where:

$X_{i}$ - the value of exports of the industry $i$,

$M_{i}$ - the value of imports of the industry $i$.

The above index takes on values from the interval $[0 ; 1]$. The higher the value of the $G L_{i}$ index, the more intense the intra-industry trade. The $G L_{i}$ index is the so-called simple Grubel-Lloyd index, which allows the intensity of intra-industry trade in individual industries to be evaluated. An aggregated measure is obtained by calculating the weighted average of the indexes for individual industries $\left(G L_{i}\right)$. Weights shall be shares of each of the industries in total trade, i.e., $\left(X_{i}+M_{i}\right) / \sum_{(i=1)}^{n}\left(X_{i}+M_{i}\right)$. The aggregate measure is expressed by the following formula:

$$
G L_{i}^{A}=\frac{\sum_{i=1}^{n}\left(X_{i}+M_{i}\right)-\sum_{i=1}^{n}\left|X_{i}-M_{i}\right|}{\sum_{i=1}^{n}\left(X_{i}+M_{i}\right)} .
$$


The indices of the intensity of intra-industry trade in agricultural and food products between Poland and European Union member states are contained in Table 1. The presented data show that in 2002-2011 there was a significant increase in the intensity of intra-industry trade turnover between Poland and almost all EU countries. A particularly favourable situation was noted during the examined period in intra-industry trade with the so-called old EU members (EU-15).

In the case of the new members, there were far smaller increases in the intensity of intra-industry trade. In the case of the trade exchange with three new members of the Community, namely, with the Czech Republic, Slovakia and Romania, intra-industry trade indices even saw a decrease.

Table 1: Intensity of intra-industry trade between Poland and European Union member states in agricultural and food products in the years 2002-2011

\begin{tabular}{|c|c|c|c|c|c|c|c|c|c|c|}
\hline Country & 2002 & 2003 & 2004 & 2005 & 2006 & 2007 & 2008 & 2009 & 2010 & 2011 \\
\hline Austria & 0.125 & 0.135 & 0.220 & 0.250 & 0.262 & 0.251 & 0.381 & 0.418 & 0.414 & 0.391 \\
\hline Belgium & 0.105 & 0.141 & 0.199 & 0.408 & 0.437 & 0.415 & 0.373 & 0.317 & 0.322 & 0.322 \\
\hline Bulgaria & 0.191 & 0.180 & 0.207 & 0.205 & 0.216 & 0.200 & 0.210 & 0.215 & 0.303 & 0.270 \\
\hline Cyprus & 0.000 & 0.000 & 0.263 & 0.187 & 0.308 & 0.380 & 0.515 & 0.430 & 0.240 & 0.238 \\
\hline Czech Republic & 0.491 & 0.490 & 0.481 & 0.500 & 0.437 & 0.489 & 0.452 & 0.404 & 0.425 & 0.425 \\
\hline Denmark & 0.331 & 0.350 & 0.370 & 0.383 & 0.398 & 0.399 & 0.340 & 0.342 & 0.379 & 0.393 \\
\hline Estonia & 0.011 & 0.024 & 0.072 & 0.081 & 0.045 & 0.121 & 0.169 & 0.107 & 0.129 & 0.144 \\
\hline Finland & 0.192 & 0.273 & 0.272 & 0.236 & 0.266 & 0.261 & 0.231 & 0.174 & 0.264 & 0.220 \\
\hline France & 0.309 & 0.311 & 0.381 & 0.471 & 0.424 & 0.407 & 0.474 & 0.445 & 0.472 & 0.474 \\
\hline Germany & 0.307 & 0.299 & 0.401 & 0.449 & 0.475 & 0.516 & 0.598 & 0.592 & 0.593 & 0.631 \\
\hline Greece & 0.055 & 0.068 & 0.105 & 0.147 & 0.211 & 0.278 & 0.183 & 0.142 & 0.245 & 0.253 \\
\hline Hungary & 0.347 & 0.379 & 0.388 & 0.317 & 0.334 & 0.373 & 0.334 & 0.305 & 0.332 & 0.421 \\
\hline Ireland & 0.029 & 0.027 & 0.066 & 0.178 & 0.317 & 0.372 & 0.400 & 0.437 & 0.423 & 0.398 \\
\hline Italy & 0.195 & 0.172 & 0.243 & 0.249 & 0.249 & 0.267 & 0.297 & 0.226 & 0.262 & 0.294 \\
\hline Latvia & 0.037 & 0.023 & 0.054 & 0.081 & 0.087 & 0.145 & 0.119 & 0.136 & 0.179 & 0.124 \\
\hline Lithuania & 0.090 & 0.159 & 0.213 & 0.328 & 0.308 & 0.353 & 0.309 & 0.332 & 0.404 & 0.382 \\
\hline Luxembourg & 0.000 & 0.000 & 0.123 & 0.034 & 0.053 & 0.129 & 0.052 & 0.042 & 0.024 & 0.079 \\
\hline Malta & 0.000 & 0.000 & 0.001 & 0.003 & 0.001 & 0.000 & 0.003 & 0.001 & 0.004 & 0.006 \\
\hline Netherlands & 0.283 & 0.300 & 0.304 & 0.363 & 0.392 & 0.445 & 0.442 & 0.475 & 0.469 & 0.461 \\
\hline Portugal & 0.043 & 0.085 & 0.142 & 0.048 & 0.089 & 0.171 & 0.164 & 0.207 & 0.212 & 0.203 \\
\hline Romania & 0.158 & 0.061 & 0.064 & 0.115 & 0.149 & 0.107 & 0.217 & 0.214 & 0.260 & 0.148 \\
\hline Slovakia & 0.349 & 0.367 & 0.407 & 0.349 & 0.357 & 0.411 & 0.334 & 0.343 & 0.358 & 0.337 \\
\hline Slovenia & 0.082 & 0.168 & 0.176 & 0.138 & 0.115 & 0.109 & 0.083 & 0.074 & 0.105 & 0.102 \\
\hline Spain & 0.060 & 0.077 & 0.118 & 0.132 & 0.139 & 0.147 & 0.158 & 0.144 & 0.164 & 0.213 \\
\hline Sweden & 0.238 & 0.274 & 0.279 & 0.260 & 0.269 & 0.282 & 0.260 & 0.298 & 0.316 & 0.312 \\
\hline United Kingdom & 0.293 & 0.296 & 0.328 & 0.323 & 0.293 & 0.325 & 0.375 & 0.346 & 0.329 & 0.342 \\
\hline
\end{tabular}

* Twenty-six of Poland's trade partners were considered and these states were members of the European Union in 2011.

Source: the author's own calculations based on the UN Comtrade Database (2013). 


\section{Model estimation}

In order to identify the factors determining Poland's intra-industry trade with European Union member states in the field of agricultural and food products, a model for panel data was constructed. The Grubel-Lloyd index set for Polish trade turnover with EU countries in the period 2002-2011 was taken as the dependent variable. The bilateral intra-industry trade indices calculated for the three-digit commodity groups were separated according to the Standard International Trade Classification. The study covered the following product sections: SITC 0 - Food and live animals, SITC 1 - Beverages and tobacco, SITC 2 Crude materials, inedible, except fuels (excluding divisions SITC 27 and SITC 28) and SITC 4 - Animal and vegetable oils, fats and waxes.

The study included 26 of Poland's trade partners that were members of the European Union in 2011. The following were taken as potential explanatory variables: GDP, GDP per capita, the index of the relative difference in trading partners' GDP, and the index of the relative difference in trading partners' GDP per capita. Also, the impact of geographical distance between countries was taken into account and was expressed in the number of kilometres between their capitals. In addition, the impact of European Union membership on the increase in the intensity of intra-industry trade was examined. For this purpose, an additional dummy variable for EU was introduced. The model also takes into account use by Poland's trade partners of a similar language, i.e., one belonging to the group of Slavic languages. Therefore, yet another dummy variable $(L A N G)$, was added to the model.

Due to the fact that the dependent variable $G L_{k t}$ is an index taking on values from the interval $[0 ; 1]$, a logit transformation of the dependent variable was performed. In this manner, we obtained a dependent variable in the form of the logit $\ln \left(G L_{k t} / 1-G L_{k t}\right)$ and this dependent variable's values are contained in the interval $(-\infty ; \infty)$. This eliminated the possibility of obtaining theoretical values of the Grubel-Lloyd index beyond the acceptable interval $[0 ; 1] .^{2}$ All independent variables, except for dummy ones, were logarithmised.

The following research hypotheses concerning the intensity of intra-industry trade in agricultural and food products between Poland and European Union member states were subject to verification:

H1: There is a positive correlation between the size of the economies of trading partners, as measured by the size of their GDP, and the intensity of intra-industry trade with these countries.

$\mathrm{H} 2$ : There is a negative correlation between relative differences in the size of the economies of trading partners (measured by the size of their GDP) and the intensity of intra-industry trade between these countries.

H3: There is a positive relationship between the level of economic development of European Union member states, as measured by the size of their GDP per capita, and the intensity of intra-industry trade between these countries.

\footnotetext{
${ }^{2}$ In cases where the index of intra-industry trade $\left(G L_{k t}\right)$ took the value of 0 , a procedure proposed by Lee and Lee (1993) was applied. It assumes that the dependent variable $\left(G L_{k t}\right)$ takes on a very small value equal to 0.0000001 and this value is substituted for the purpose of logarithmisation.
} 
H4: There is a negative correlation between relative differences in income per capita of trading partners and the intensity of intra-industry trade.

H5: The degree of trade imbalance between trading partners negatively impacts the intensity of mutual intra-industry trade.

H6: There is a positive relationship between the intensity of trade exchange between countries, as measured by the share of a specific trading partner in the total of Poland's trade in agricultural and food products, and the intensity of mutual intraindustry trade.

H7: There is a negative correlation between the geographical distance which divides trading partners and the intensity of their mutual intra-industry trade.

H8: EU membership significantly increases the intensity of intra-industry trade.

H9: A similar language, i.e. one belonging to the group of Slavic languages, which is an official language in the countries that trade with Poland, significantly increases the intensity of mutual intra-industry trade.

The assumed research hypotheses allowed the model specification for panel data:

$$
\begin{gathered}
G L_{k t}=\alpha_{0}+\alpha_{1} G D P_{k t}+\alpha_{2} D G D P_{k t}+\alpha_{3} P C I_{k t}+\alpha_{4} D P C I_{k t}+ \\
\alpha_{5} T I M B_{k t}+\alpha_{6} T I_{k t}+\alpha_{7} D I S T_{k}+\alpha_{8} U E_{k t}+\alpha_{9} L A N G_{k}+v_{k t} \\
v_{k t}=e_{t}+u_{k}+\varepsilon_{k t},
\end{gathered}
$$

The description of the variables and sources of data used are shown in Table 2.

Table 2: Variables used in empirical investigation

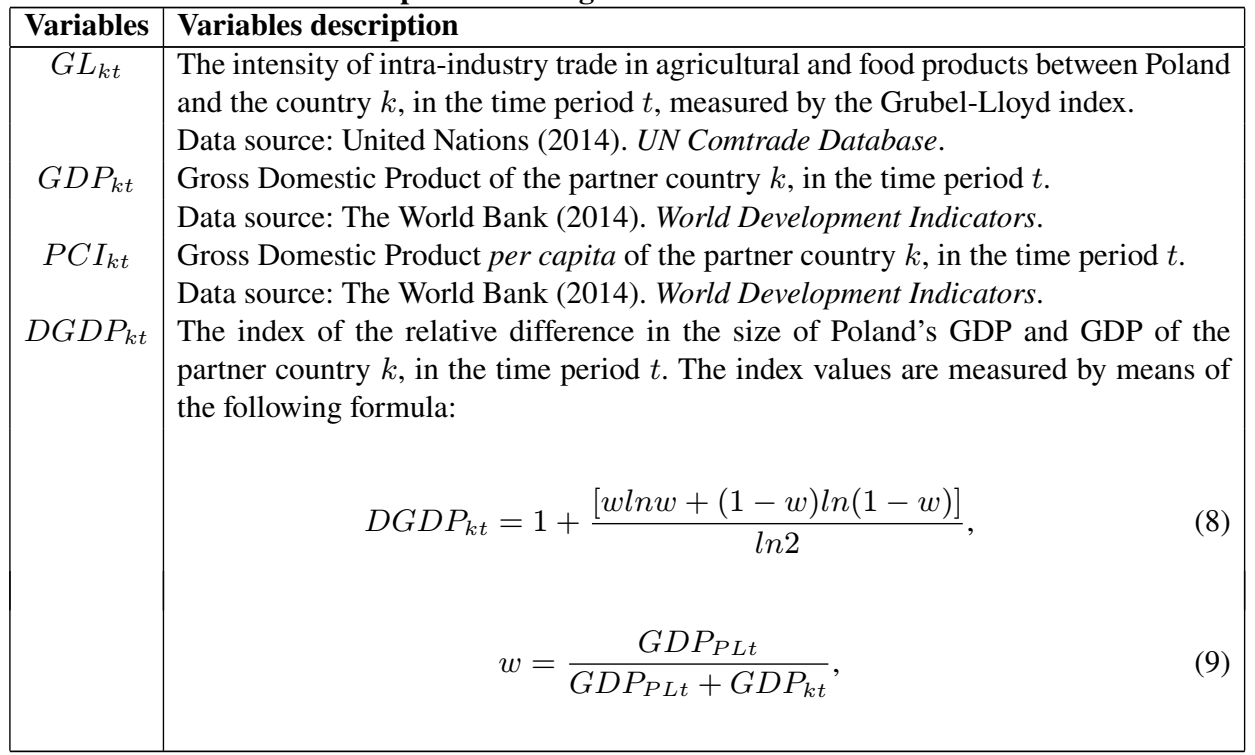




\begin{tabular}{|c|c|}
\hline Variables & Variables description \\
\hline \multirow{6}{*}{$D P C I_{k t}}$, & where: $G D P_{P L t}, G D P_{k t}-$ the size of Poland's GDP and GDP of the partner country \\
\hline & $k$, in the time period $t$. \\
\hline & The above index takes on values from the interval $[0 ; 1]$. If the differences in GDP \\
\hline & between countries are large, then the index approaches the value of 1 . When GDP is \\
\hline & P \\
\hline & $\begin{array}{l}\text { The index of the relative difference in Poland's GDP income per capita and in GDP } \\
\text { of its partner country } k \text {, in the time period } t \text {. The index values are calculated with the } \\
\text { use of the formula constructed as in the case of DGDPkt. }\end{array}$ \\
\hline$E U_{k t}$ & $\begin{array}{l}\text { The dummy variable takes on the value } 1 \text {, if in the year } t \text {, Poland and its trading } \\
\text { partner } k \text { were EU member states, and takes on the value } 0 \text {, if the two countries, or } \\
\text { one of them, did not belong to the European Union. }\end{array}$ \\
\hline \multirow[t]{2}{*}{$T I M B_{k t}$} & $\begin{array}{l}\text { The degree of trade imbalance of trade exchange in agricultural and food products } \\
\text { between Poland and the country } k \text {, in the year } t \text {. The variable was designated as the } \\
\text { share of the trade balance with the partner } k \text { in total turnover of agricultural and food } \\
\text { products. }\end{array}$ \\
\hline & Data source: United Nations (2014). UN Comtrade Database. \\
\hline \multirow[t]{2}{*}{$T I_{k t}$} & $\begin{array}{l}\text { The share of the country } k \text { in Poland's total trade turnover in products of the agricul- } \\
\text { tural and food industry, in the year } t \text {. }\end{array}$ \\
\hline & (2014). UN Comtrade Database. \\
\hline$L A N G_{k}$ & $\begin{array}{l}\text { The dummy variable takes on the value } 1 \text {, when the language of Poland's trading } \\
\text { partner is a Slavic language, and equals } 0 \text {, when it is not a Slavic language. }\end{array}$ \\
\hline$D I S T_{k}$ & The geographical distance between the capitals of Poland and its trading partner $k$. \\
\hline & $\begin{array}{l}\text { Data source: Centre D'Etudes Prospectives et D'Informations Internationales (2014). } \\
\text { GeoDist. }\end{array}$ \\
\hline$v_{k t}$ & The random error in the object $k$, in the time period $t$, which consists of the following \\
\hline & \\
\hline & $e_{t}-$ impulses affecting all observations in the time period $t$, \\
\hline & $u_{k}-$ impulses affecting all the \\
\hline & $\varepsilon_{k t}-$ impulses affecting only obs \\
\hline
\end{tabular}

Source: elaborated by the author.

The estimation of the panel data model, designated with formula (6) was made with the use of the Gretl software ${ }^{3}$, version 9.1.14. There were no a priori assumptions made for the occurrence and significance of individual effects, as well as for the character of the individual effects (fixed or random). The choice of estimation methods (pooled OLS, fixed effects, random effects) was made with the use of a decision procedure from the field of econometrics advocated in the literature (see, for instance: Baltagi, 2001; Muszyńska 2006). The model is estimated with the use of a least squares method and diagnostic tests were performed. The results of the diagnostic tests are shown in Table 3.

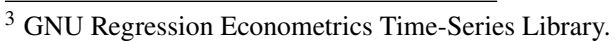


Table 3: Test statistics and significance levels in the diagnostic tests of the model of intraindustry trade in agricultural and food products between Poland and EU countries

\begin{tabular}{|c|cc|}
\hline Diagnostic test & Test statistic & p-value \\
\hline Wald test & $\mathrm{F}=13,157$ & $<0,00001$ \\
Breusch-Pagan test & $\mathrm{LM}=103,707$ & $<0,00001$ \\
Hausman test & $\mathrm{H}=63,384$ & $<0,00001$ \\
\hline
\end{tabular}

Source: the author's own calculations.

Based on the diagnostic tests conducted, it was found that a suitable model for studying the impact of the macroeconomic determinants of the intensity of intra-industry trade is a model with fixed effects $(F E)$. Therefore, model parameters with fixed effects were estimated. However, the phenomenon of heteroscedasticity occurred, that is the nonhomogeneity of the random components variance within the sample.

Heteroscedasticity affects inappropriate estimations of standard errors for individual parameters and the revaluation of the determination coefficient, which may distort the conclusions regarding the significance of variables. Therefore, to ultimately estimate the parameters, the weighted least-squares method was applied $(W L S)$.

\section{Results}

The values of the statistically significant parameters of the model described with formula (6) are contained in Table 4.

Table 4: Results of the estimation of the model describing Poland's intra-industry trade in agricultural and food products with the use of country-specific determinants

\begin{tabular}{|c|c|c|c|c|c|}
\hline \multicolumn{6}{|c|}{$\begin{array}{c}\text { Dependent variable } \\
\ln \left(G L_{k t} / 1-G L_{k t}\right)\end{array}$} \\
\hline $\begin{array}{l}\text { Independent } \\
\text { variables }\end{array}$ & Coefficient & $\begin{array}{r}\text { Standard } \\
\text { error }\end{array}$ & $t$-statistics & $p$-value & Significance $^{a)}$ \\
\hline Constant & -0.9384 & 0.9521 & -0.986 & 0.3253 & \\
\hline$T I M B_{k t}$ & -0.1323 & 0.0343 & -3.859 & 0.0001 & $* * *$ \\
\hline$T I_{k t}$ & 0.6660 & 0.0432 & 15.430 & $<0.00001$ & $* * *$ \\
\hline$D G D P_{k t}$ & -0.0335 & 0.0178 & -1.885 & 0.0606 & $*$ \\
\hline$P C I_{k t}$ & 0.1512 & 0.0903 & 1.674 & 0.0954 & $*$ \\
\hline$D P C I_{k t}$ & -0.0548 & 0.0204 & -2.688 & 0.0077 & $* * *$ \\
\hline$L A N G_{k}$ & 0.7232 & 0.1340 & 5.398 & $<0.00001$ & $* * *$ \\
\hline$U E_{k t}$ & 0.5809 & 0.1119 & 5.190 & $<0.00001$ & $* * *$ \\
\hline \multicolumn{2}{|c|}{ Observations } & \multicolumn{4}{|c|}{260} \\
\hline \multicolumn{2}{|c|}{ Standard error of residuals } & \multicolumn{4}{|c|}{0.794366} \\
\hline \multicolumn{2}{|c|}{$\mathrm{R}^{2}$} & \multicolumn{4}{|c|}{0.664572} \\
\hline \multicolumn{2}{|c|}{ Adjusted $\mathrm{R}^{2}$} & \multicolumn{4}{|c|}{0.655255} \\
\hline \multicolumn{2}{|c|}{$\mathrm{F}(7,252)=71,32568$} & \multicolumn{4}{|c|}{$p$-value for test $\mathrm{F}<0,00001$} \\
\hline
\end{tabular}

a) $*$ Statistically significant variable at the level of $10 \%$, *** Statistically significant variable at the level of $1 \%$.

Source: the author's own calculations. 
The above model is statistically correct. Seven out of the nine potential explanatory variables proved to be significant. In the model all of the obtained signs for parameter estimates for a particular explanatory variable are consistent with the predictions of the theory. The general performance of the model is satisfactory (Adjusted $\mathrm{R}^{2}=0.6552$ ).

When interpreting the results obtained in relation to the variables that were previously logarithmised, the following interpretation method can be used: an increase in the explanatory variable by $1 \%$ causes ceteris paribus an increase or decrease (depending on the sign of the parameter) in the dependent variable of $\alpha \%$ (the parameter for a specific explanatory variable). In this case, the dependent variable is the logit, which means that the relation $G L_{k t} / 1-G L_{k t}$ changes by $\alpha \%$, which is the relation of intra-industry trade $\left(G L_{k t}\right)$ and inter-industry trade $\left(1-G L_{k t}\right)$.

The results of the research confirm that the factor that significantly and at the same time positively affects the growth of the intra-industry trade indices is the degree of the intensity of trade exchange between Poland and its trading partners (the variable $T I_{k t}$ ). The intensity of trade was expressed by the share of individual partners in Poland's total trade turnover in agricultural and food products. The resulting value of the parameter $\alpha$ for the variable TIkt indicates that the average increase in the intensity of trade between the countries by $1 \%$, causes a slightly smaller than the proportional (almost by $0.6 \%$ ) increase in intra-industry trade relative to inter-industry trade. The research hypothesis H6 was verified positively. The variable that significantly and also positively affects the intensity of intra-industry trade is the size of GDP per capita achieved by Poland's trade partners. This variable represents the level of economic development of individual countries. The impact strength of this factor, however, is smaller, as indicated by the parameter $\alpha$, for the variable $P C I_{k t}$, which is 0.1512 . The research hypothesis $\mathrm{H} 3$ was verified positively.

A factor that significantly but the same time negatively affects the intensity of intraindustry trade is also the degree of trade imbalance in agricultural and food products between Poland and EU countries. The value of the parameter $\alpha$ of the variable TIMB $B_{k t}$ was -0.1323 . Hypothesis $\mathrm{H} 5$ was verified positively.

Statistically significant, though of a smaller impact strength, were the determinants describing the relative differences in the size of the economies and relative differences in the level of the economic development of Poland and its EU trading partners. The study confirms that an increase in the differences of the size of trading countries' GDP (the variable $\left.D G D P_{k t}\right)$ has a negative impact on the intensity of intra-industry trade $(\alpha=-0.0335)$. It is similar in the case of the differences in GDP per capita between Poland and its trading partners. Variable $D P C I_{k t}$ has a negative impact on the intensity of this exchange $(\alpha=-0.0548)$. With respect to these variables $\left(D G D P_{k t}\right.$ and $\left.D P C I_{k t}\right)$, the signs obtained were consistent with the predictions of the theory, which led to a positive verification of the research hypotheses $\mathrm{H} 2$ and $\mathrm{H} 4$.

Within the estimated model, two dummy variables proved to be statistically significant. One of them $\left(E U_{k t}\right)$ is related to Poland's and its trading partners' EU membership. This variable had the value of 1 in the years when Poland and its trading partner were members of the European Union, and had the value of 0 when one of the countries (Poland, or its trading partner) or both countries (Poland and its trading partner) did not belong to the 
EU. The other variable ( $L A N G_{k}$ ) describes the cultural ties of trading partners, expressed by the affiliation of a trading partner's language to the Slavic language group. In the case of the dummy variables $U E_{k t}$ and $L A N G_{k}$ based on the evaluation of the sign of the parameter estimate for a particular explanatory variable, one can specify only the direction of the impact of this variable on the dependent variable. A positive relationship between partners' EU membership and the intensity of their mutual intra-industry trade can be inferred from the obtained results. A positive impact on the intensity of bilateral trade also occurs when the population of a country being Poland's trading partner uses as their primary language a language which is a member of the Slavic group of languages. The results obtained are consistent with the predictions of theory and allow the positive verification of the research hypotheses $\mathrm{H} 8$ and $\mathrm{H} 9$.

The variables $G D P_{k t}$ and $D I S T_{k}$ proved to be statistically insignificant. Therefore, the remaining research hypotheses failed to be verified positively.

\section{Conclusion}

The simultaneous import and export of similar products in the same industry plays an increasingly important role in Poland's trade with European Union member states. This also applies to agricultural and food products. The present work identified the factors that determine Poland's intra-industry trade with EU countries in agricultural and food products. The focus was on the features of the economies of the countries participating in that exchange, i.e. on country-specific determinants.

The research conducted shows that the development of this type of trade exchange in Poland is positively influenced by the intensity of trade with European Union countries and by the level of economic development of the member states (as measured by the size of their GDP per capita). The development of intra-trade turnover is also encouraged by such factors as EU membership and the fact that Poland's trade partners use similar Slavic languages. The relative differences in the size of the economies and the relative differences in Poland's and its trading partners' levels of economic development have a negative impact. The degree of the trade imbalance between trading partners also negatively influences the intensity of mutual intra-trade exchange. The study confirmed that the impact of all of the identified determinants of intra-industry trade is consistent with the predictions of the theory.

\section{References}

Balassa, B., Bauwens, L. (1987). Intra-Industry Specialisation in a Multi-Country and Multi-Industry Framework. The Economic Journal, 97, 923-939.

Baltagi, B. H. (2001). Econometric Analysis of Panel Data, (2 ${ }^{\text {nd }}$ ed.). Chichester: John Wiley \& Sons.

Van Bergeijk P. A. G., Brakman S. (2010). The Gravity Model in International Trade: Advances and Applications. Cambridge: Cambridge University Press. 
Bergstrand, J. H. (1990). The Heckscher-Ohlin-Samuelson Model, the Linder hypothesis and the determinants of bilateral intra-industry trade. The Economic Journal, 100, 1216-1229.

Botrić, V. (2013). Determinants of Intra-industry Trade between Western Balkans and EU-15: Evidence from Bilateral Data. International Journal of Economic Sciences and Applied Research, 6(2), 7-23.

Byun, J. J., Lee, S.-H. (2005). Horizontal and Vertical Intra-Industry Trade: New Evidence from Korea, 1991-1999. Global Economy Journal, 5(1), 1-29.

Centre D'Etudes Prospectives et D'Informations Internationales. (2014). GeoDist. Retrieved on April 25, 2014, from http://www.cepii.fr/anglaisgraph/bdd/distances.htm.

Cieślik, A. (2000). Nowa teoria handlu zagranicznego w świetle badań empirycznych. Warszawa: Wydawnictwo Naukowe PWN.

Clark, D. P., Stanley, D. L. (1999). Determinants of Intra-Industry Trade Between Developing Countries and the United States. Journal of Economic Development, 24(2), 79-95.

Crespo, N., Fontoura, M. P. (2004). Intra-Industry Trade by Types: What Can We Learn from Portuguese Data? Review of World Economics, 140(1), 52-79.

Czarny, E., Śledziewska, K. (2009). Polska w handlu światowym. Warszawa: Polskie Wydawnictwo Ekonomiczne.

Czarny, E. (2002). Teoria i praktyka handlu wewnatrzgateziowego. Warszawa: Oficyna Wydawnicza Szkoły Głównej Handlowej.

Ekanayake, E. M. (2001). Determinants of Intra-Industry Trade: The Case of Mexico. The International Trade Journal, 15(1), 89-112.

Globerman, S., Dean, J. W. (1990). Recent Trends in Intra-Industry Trade and Their Implications for Future Trade Liberalization. Weltwirtschaftliches Archiv, 126(1), 25-49. Grubel, H. G., Lloyd, P. J. (1975). Intra-Industry Trade: The Theory and Measurement of International Trade in Differentiated Products. London: Macmillan.

Helpman, E. (1987). Imperfect Competition and International Trade: Evidence from Fourteen Industrial Countries. Journal of the Japanese and International Economies, 1, 62-81. Helpman, E., Krugman, P. R. (1985). Market Structure and Foreign Trade: Increasing Returns, Imperfect Competition, and the International Economy. Cambridge Massachusetts: MIT Press.

Łapińska, J. (2003). Metodologia pomiaru strumieni handlu wewnątrzgałęziowego. Acta Universitatis Nicolai Copernici Ekonomia XXXIII, 367, 113-127.

Lee, H.-H., Lee, Y.-Y. (1993). Intra-Industry Trade in Manufactures: The Case of Korea. Weltwirtschaftliches Archiv, 129(1), 159-171.

Lee, H.-H., Sohn, Ch.-H. (2004). South Korea's Marginal Intra-Industry Trade and Choice of Preferential Partners. Asian Economic Papers, 3(3), 94-116.

Leitão, N.C. (2011). Intra-industry trade in the agriculture sector: The experience of United States. African Journal of Agricultural Research, 6(1), 186-190.

Linder, S. B. (1961). An Essay on Trade and Transformation. Stockholm: John Wiley \& Sons; Almqvist \& Wiksell.

Loertscher, R., Wolter, F. (1980). Determinants of Intra-Industry Trade: Among Countries and Across Industries. Weltwirtschaftliches Archiv, 116(2), 280-293. 
Markusen, J. R., Venables, A. J. (1996). The Theory of Endowment, Intra-Industry and Multinational Trade, NBER Working Paper No 5529. Retrieved on April 17, 2014, from http://www.nber.org/papers/w5529.pdf?new_window=1.

Mulenga, M. C. (2012). An Investigation of the Determinants of Intra-Industry Trade Between Zambia and its Trading Partners in the Southern African Development Community $(S A D C)$. TIPS Working Paper Series. Retrieved on April 17, 2014, from http://www.tips. org.za.

Muszyńska, J. (2006). Modelowanie danych panelowych. Zeszyty Naukowe Państwowej Wyższej Szkoły Zawodowej we Włocławku, 1, 213-236.

Niem, L. D., Kim, T. (2010). Technology, Preference for Quality, and Vertical IntraIndustry Trade. Modern Economy, 1, 129-133.

Okubo, T. (2007). Intra-Industry Trade, Reconsidered: The Role of Technology Transfer and Foreign Direct Investment. The World Economy, 30(12), 1855-1876.

Onogwu, G. O. (2013). Regional Characteristics Effects on Intra-Industry Trade in Residues and Wastes from Food Mill Industry. Journal of Agriculture and Sustainability, 3(1), 108-121.

Pietrzak, M. B., Łapińska, J. (2014). Zastosowanie modelu grawitacji do identyfikacji czynników determinujących przepływy handlowe w Unii Europejskiej. Przeglad Statystyczny, 61(4), 65-77.

Ramakrishnan, A., Varma, P. (2014). Do free trade agreements promote intra-industry trade? The case of India and its FTAs. International Journal of Trade and Global Markets, $7(2), 129-144$.

Sotomayor, M. (2012). Patterns and Determinants of Intra-Industry Trade for the Mexican Non-Maquiladora Manufacturing Industry. The Journal of Business Inquiry, 11(1), 33-57. Sudsawasd, S. (2012). Trade Integration in East Asia: An Empirical Assessment. Modern Economy, 3, 319-329.

The World Bank. (2014). World Development Indicators. Retrieved on April 25, 2014, from http://data.worldbank.org/data-catalog/world-development-indicators.

Thorpe, M., Zhang, Z. (2005). Study of the Measurement and Determinants of IntraIndustry Trade in East Asia. Asian Economic Journal, 19(2), 231-247.

Turmo, J., Hervitz, H. M., Moslares, C. (2005). An Analysis of the Determinants of IntraIndustry Trade: The Case of Spanish Foreign Trade. International Business \& Economic Research Journal, 4(3), 53-62.

United Nations. (2014). UN Comtrade Database. Retrieved on April 17, 2014, from http://comtrade.un.org/data/.

Vona, S. (1991). On the Measurement of Intra-Industry Trade: Some Further Thoughts. Weltwirtschaftliches Archiv, 127(4), 678-700.

Wakasugi, R. (2007). Vertical Intra-Industry Trade and Economic Integration in East Asia. Asian Economic Papers, 6(1), 26-39.

Zhang, Y., Clark, D. P. (2009). Pattern and Determinants of United States' Intra-Industry Trade. The International Trade Journal, 23(3), 325-356.

Zhang, Z., Li, C. (2006). Country-Specific Factors and the Pattern of Intra-Industry Trade in China's Manufacturing. Journal of International Development, 18, 1137-1149. 